\title{
Treść i przesłanie modlitwy Jezusowej ze szczególnym uwzględnieniem nauki św. Marka Eugenikosa*
}

\author{
ks. Adam Magruk \\ Wydział Teologiczny Chrześcijańskiej Akademii Teologicznej \\ Prawosławne Seminarium Duchowne \\ Warszawa, Polska \\ admagruk@wp.pl
}

rev. A. Magruk, The Content and Message of the Jesus Prayer with Particular Attention Given to the Teaching of St. Mark of Ephesus, Elpis, 20 2018: 145-150.

\begin{abstract}
The article addresses the issue of the Jesus prayer as interpreted by the great man and father of the Church, St. Mark of Ephesus. The hierarch chiefly bases his reflections on the message found in Holy Scripture and patristic heritage. Particular attention is given to the difference between the Greek terms: $\theta \varepsilon \omega \rho i \alpha$ and $\pi \rho \tilde{\alpha} \xi 1 \varsigma$.

Both of these words contained in the prayer have an exceptional message, both historically and theologically.

The prayer of the heart, while short in content, and vast in meaning, reveals God's wisdom and power. The fruits of this prayer, according to the holy hierarch, are enjoyed by those who do not simply admire it, but undertake the labour of practicing and nurturing it in daily life.
\end{abstract}

\begin{abstract}
Streszczenie: Artykuł podejmuje problematykę modlitwy Jezusowej w interpretacji wielkiego męża i ojca Kościoła św. Marka Eugenikosa. Hierarcha swoje rozważania opiera w głównej mierze na przesłaniu Pisma Świętego oraz spuściźnie patrystycznej. Szczególny nacisk kładzie on na rozróżnienie greckich pojęć takich jak: $\theta \varepsilon \omega \rho i ́ \alpha$ oraz $\pi \rho \tilde{a} \xi ı$.

Każde ze słów tego modlitewnego wezwania niesie za sobą wyjątkowe - zarówno historyczne, jak i teologiczne przesłanie.

Krótka objętościowo, ale obszerna w przekazie modlitwa serca odkrywa cząstkę mądrości i mocy Bożej. Owoce, które skrywa ona w sobie - zgodnie z zapewnieniem św. hierarchy - skosztują ci, którzy nie poprzestaną jedynie na jej podziwianiu, ale podejmą się jego trudu jej praktykowania i pielęgnowania w życiu codziennym.
\end{abstract}

Keywords: prayer, Jesus prayer, prayer of the heart, theory, practice, sin

Słowa kluczowe: modlitwa, modlitwa Jezusowa, modlitwa serca, teoria, praktyka, grzech

\section{Wstęp}

„Mieczem duchowym”, „Boską Modlitwą”, „najkrótszą drogą ku osiągnięciu Królestwa Niebieskiego"3, „wyznaniem wiary” ${ }^{\prime}$ i „,narzędziem komunii z Duchem Świętym” nazywali święci słynny tekst: „Panie Jezu Chryste, Synu Boży, zmiłuj się nade mną" (gr. Kúple 'I parafrazując biskupa Jerzego (Pańkowskiego) - która jak żadna inna nie zna granic czasu oraz miejsca, aczkolwiek doskonałymi warunkami do jej wygłaszania jest bez-

\footnotetext{
Artykuł stanowi wynik realizacji projektu badawczego pt. Wybrane elementy życia liturgicznego w nauczaniu świętego Marka biskupa Efezu Eugenikosa (etap III), finansowanego z dotacji celowej na prowadzenie badań naukowych i prac rozwojowych, służących rozwojowi młodych naukowców oraz uczestników studiów doktoranckich w Chrześcijańskiej Akademii Teologicznej w Warszawie (2016).

1 Не оставляй Божественной молитвы. Оптинские стариьы о молитве Иисусовой, red. посл. Зоя Афанасьева, Святая Гора Афон 2014, s. 4.

2 Tamże.

3 Tamże, s. 17.

4 Блаж. Симеон Солунский, Обяснение православных богослужений, обрядов и таинств, wyd. Оранта, Москва 2009, s. 350.

5 Tamże, s. 351.
}

względnie atmosfera wyciszenia i milczenia (gr. $\dot{\eta} \sigma v \chi i \alpha)^{6}$. Modlitwa ta stała się wyjątkowo bliska sercu św. Marka Eugenikosa, której sam za dnia poświęcał wiele godzin, ale też nikt nie jest w stanie zliczyć, ile nieprzespanych nocy spędził na obcowaniu $\mathrm{z}$ nią. W przeciwnym wypadku biskup Kaukazu i Morza Czarnego Ignacy zapewne nie odważyłby się tak o nim powiedzieć: „Marek Efeski zajmował się duchową modlitwą rozumu, co czynili tylko najwięksi święci" ". Prawdą jest, że w osobnym, poruszającym wyłącznie tę tematykę traktacie Eugenikos nie mówi dosłownie nic na temat techniki jej wykonywania, a więc: synergii duszy i ciała, pokłonach, wysiłku fizycznym, odpowiedniej kontroli oddechu itp. Co niezwykle istotne, rekomenduje on jej odmawianie, nie tylko ,ziemskim aniołom" (mnichom), lecz każdemu, kto łaknie osobistej relacji z Chrystusem.

\footnotetext{
Zob. J. Pańkowski, Duchowość w prawostawiu prawosławiu, [w:] Przeglad Religioznawczy, wyd. Polskie Towarzystwo Religioznawcze, Warszawa 2012, Nr 2 (244), s. 87-88.

7 Святитель Игнатий (Брянчанинов), Письмо к А.С. Норову. № 3, [w:] Полное собрание творений святителя Игнатия Брянчанинова, t. VI, red. А.Н. Стрижев, wyd. Паломник, Москва 2004, s. 774.
} 


\section{Biblijne dowody pochodzenia słów modlitwy Jezusowej}

W poszukiwaniu źródła modlitwy Jezusowej, według św. hierarchy Efezu zwrócić się należy do przekazu apostolskiego nauczania ${ }^{8}$. Już pierwszy z nią kontakt udowadnia słuszność powyższej oceny biskupa. Boskie imiona zostały w niej zapisane w określonej kolejności nieprzypadkowo. Porządek ten odnosi do przekazu biblijnego. Stary Testament nader często nazywa hipostazę Logosu „Panem”, np. „Pan spuścił na Sodomę i Gomorę deszcz siarki i ognia od Pana” (Rdz 19, 24) oraz: „Powiedział Pan do Pana mego” (Ps 109, 1). W Nowym Testamencie natomiast archanioł, zwiastujący dobrą nowinę Dziewicy Marii, poleca nadanie jej pierworodnemu imienia ,Jezus” (Łk 1, 31), ,gdyż jako Bóg, Pan wszystkich rzeczy, zechciał w swym Wcieleniu stać się naszym Zbawicielem (bo tak właśnie wykłada się imię «Jezus»)" ". Św. Jan Teolog w epilogu swej Ewangelii tak uzupełnia powyższe: „Jezus jest Chrystusem, Synem Bożym" (J 20, 31), a Piotr apostoł w mowie do zebranych w Jerozolimie na święto Pięćdziesiątnicy podsumowuje: „Niech więc cały dom Izraela wie z niewzruszoną pewnością, że tego Jezusa, Którego wyście ukrzyżowali, uczynił Bóg i Panem, i Chrystusem" (Dz 2, 36) ${ }^{10}$.

„Uczniowie Jezusa - kontynuuje św. Marek - przejęli ją jako ojcowskie dziedzictwo i przekazali dla nas, aby wszystkim stało się jasnym (...), że słowa tej świętej modlitwy (gr. $\varepsilon \dot{x} \chi \eta)$ pełne są natchnienia i objawienia Ducha Bożego, ponieważ to Sam Chrystus nauczył jej swoich apostołów i wszystkiego tego, co mają napisać i głosić światu"11. Eugenikos zawęża krąg jej autorów - przynajmniej, jeżeli chodzi o pierwszych pięć wyrazów - do trzech uczniów Zbawiciela: Pawła, Jana i Piotra. Apostoł Pogan, pouczając mieszkańców Koryntu głosi: „Nikt nie może powiedzieć, że Jezus jest Panem, bez pomocy Ducha Świętego" (I Kor 12, 3). Posługując się wyrażeniami o zabarwieniu kontrastowym, Paweł uwypukla jeszcze dobitniej fakt, iż wezwanie Tego św. imienia jest czymś niebagatelnym, doniosłym oraz przewyższającym wszelkie inne inwokacje. Drugi z wymienionych jest kontynuatorem myśli poprzedniego. Rozpoczyna on rozszerzanie modlitwy dokładnie od tego samego słowa, na którym „zatrzymał się” św. z Tarsu: „każdy duch, który uznaje, że Jezus Chrystus przyszedł w ciele, jest z Boga" (I J 4, 2). W odróżnieniu do niego, Jan Teolog używa w tym miejscu zdania twierdzącego. Umiołowany uczeń Zbawiciela przypisuje także łasce Parakleta prawdziwe wyznanie Wcielonego Słowa. „Gorący” (gr. $\theta \varepsilon \rho \mu o ́ \varsigma))^{12}$ Piotr z kolei, świadcząc o swo-

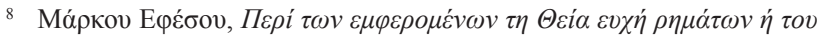

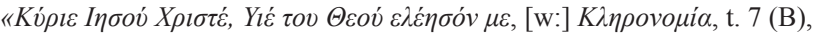

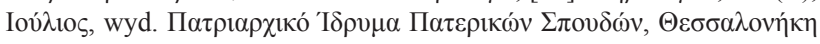
1975 , s. 351

9 Tamże, s. 347

10 Tamże, s. 351.

11 Tamże.

12 Epitet, jakiego Marek Efeski używa wobec apostoła Piotra, nawiązuje do impulsywnego usposobienia i gwałtownego temperamentu, które go cechowały i wyróżniały od innych uczniów Chrystusa.
}

jej wierze w Nauczyciela: „Ty jesteś Chrystusem, Synem Boga żywego" (Mt 16,16), również nie czyni tego bez pomocy i natchnienia Ojca Niebieskiego (Mt 16, 17), które jak uczy biskup Efezu równoznaczne jest z pojęciem łaski Św. Ducha ${ }^{13}$. Wobec tego modlitwę serca śmiało można określić jako „pneumatoforyczną”, ale i „apostolską". Każdy przecież z trzech cytowanych, w procesie powstawania jej tekstu, skutecznie i bardzo wymownie uzupełnia swego przedmówcę. „Jeden mówi: «Panem jest Jezus», drugi: «Jezus Chrystus», a kolejny dodaje: «Chrystus jest Synem Boga». Koniec łączy się z początkiem, a początek z końcem, tworząc swoisty krąg, ponieważ powiedzieć: «Pan», to tak, jakby rzec «Syn Boży», gdyż oba świadczą o Boskości Jednorodzonego Syna, Jego równości i współistotności z Ojcem"14. Modlitewna tradycja, która zapoczątkowana została przez Pawła - powołanego do służby apostolskiej, jako ostatni z wymienionych - podtrzymana została przez Jana i zachowana przez tego, który swą żarliwością najbardziej zbliżył się do Jezusa, tj. Piotra. Św. Marek thumaczy, że powód, dla którego apostołowie ci zostali przytoczeni właśnie w tej, a nie innej kolejności, symbolicznie wskazuje na klucz ku osiągnięciu harmomonii i komunii ze swoim Stwórcą. Apostoł Paweł to ikona praktyki (gr. $\pi \rho \tilde{\alpha} \xi \iota \varsigma$ ), Jan z kolei to promotor tego, co w języku greckim określa się mianem $\theta \varepsilon \omega \rho i \alpha$, zaś Piotra charakteryzuje miłość (gr. $\alpha \gamma \alpha ́ \pi \eta)$, której nie byli w stanie dorównać inni uczniowie ${ }^{15}$. Warto w tym momencie zatrzymać się nad tym arcyważnym dla prawosławnej duchowości rozróżnieniem, które proklamuje św. metropolita.

Termin $\pi \rho \tilde{\alpha} \check{\zeta} \iota \varsigma$ pochodzi od czasownika $\pi \rho \alpha ́ \tau \tau \omega$, oznaczającego m.in.: „praktykowanie”, „postępowanie”, ,ćwiczenie”, „zajmowanie się (czymś)”. Nie powinno być ono rozpatrywane wyłącznie jako zwykła praca, czy nawet służba o charakterze misjonarskim. Podobnie rzecz się ma w przypadku $\theta \varepsilon \omega \rho i \alpha$, które często błędnie tłumaczy się jako: poznanie prawdy oparte na teoretycznych spekulacjach $^{16}$. Jeden z najwybitniejszych teologów XX w. ks. Ioannis Romanidis ${ }^{17}$ wraz z G. Babiniotisem ${ }^{18}$, etymologię słowa $\theta \varepsilon \omega \rho i ́ \alpha$ wywodzą od dwóch wyrazów o bardzo podobnym znaczeniu, a mianowicie: $\theta \varepsilon \dot{\varepsilon} \alpha$ - ,patrzenie”, ,widok” oraz ó $\alpha \dot{\omega} \omega$ - ,,spoglądać”, ,patrzeć”, „,baczyć”, ,zwracać uwagę". W myśl św. Grzegorza z Nazjanzu $\pi \rho \tilde{\alpha} \xi ̌ l \varsigma$ jest

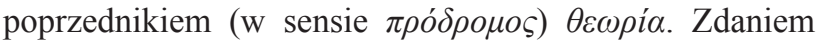
E. Ekdikosa ${ }^{19}$, pierwsze będzie oznaczało trud postu oraz

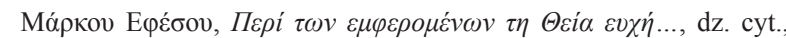
s. 348 .

14 Tamże.

15 Tamże.

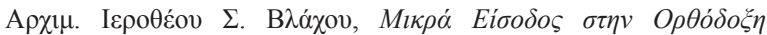

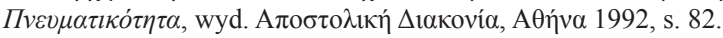

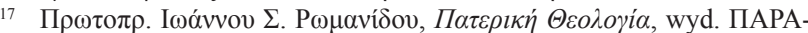

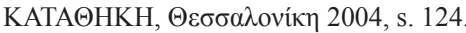

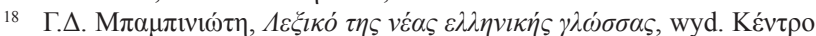
$\Lambda \varepsilon \xi ı к о \lambda о \gamma i ́ \alpha \varsigma$ Е.П.Е., А $\theta$

19 Jedenastowieczny autor licznych pism o tematyce duchowo-ascetycznej. O jego życiu nie wiadomo praktycznie nic, oprócz faktu, że był hieromnichem w jednej ze świątyń Konstantynopola oraz komentatorem dzieł św. Grzegorza Teologa. М.М. Бернацкий, Илия Э́кдик, [w:] Православная энциклопедия, t. 22, wyd. Церковно-научный центр Рус-
} 


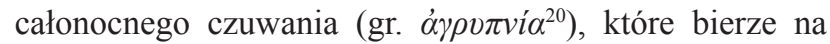
swoje ramiona wierny, czytanie psalmów oraz milczenie. Drugie zaś - zgodnie z pouczeniem Izzaka Syryjczyka -

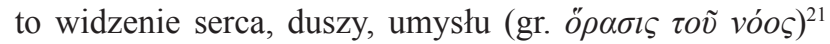

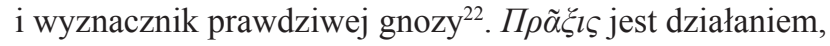
ascezą ciała i duszy oraz nieustanną duchowa walką, z kolei $\theta \varepsilon \omega \rho i ́ \alpha$ to kontemplacja, skupienie wszystkich swoich myśli na Panu Nieba i Ziemi, to wzniesienie ludzkich serc nad tym, co ziemskie, przemijające i skoncentrowanie się nad sposobem powrotu do stanu życia Prarodziców w raju. Patrystyczna empiria upatruje w $\pi \rho \tilde{\alpha} \xi ı$ dążenie ku oczyszczeniu serca ${ }^{23}$, ciągłej metanoi, ale i duchową metodę wspomagającą katharsis namiętnej części duszy ${ }^{24}$, zaś w $\theta \varepsilon \omega \rho i ́ \alpha$ uświęcenie umysłu, jak również sposobność do oglądania niestworzonej chwały Boga (przebóstwienie) ${ }^{25}$. Jedno prowadzi ku drugiemu. W tym miejscu nie sposób nie wspomnieć jednego z błogosławieństw z kazania na górze: „Błogosławieni czystego serca, albowiem oni Boga oglądać będą" (Mt 5,8). Nie może być mowy o $\pi \rho \tilde{\alpha} \xi ı \varsigma$ w oderwaniu od $\theta \varepsilon \omega \rho i ́ \alpha$ i na odwrót ${ }^{26}$. Dla neptycznego ${ }^{27}$ ojca VII w. Maksyma Wyznawcy: ,„$\theta \varepsilon \omega \rho i \alpha$ bez $\pi \rho \tilde{\alpha} \xi ı \varsigma$ jest jak sucha teoria, nieposiadająca oparcia w praktyce i jako taka nie różni się niczym od złudnej fantazji. Lecz i $\pi \rho \tilde{\alpha} \xi l \varsigma$ bez duszy- $\theta \varepsilon \omega \rho i ́ \alpha$ nie przynosi nikomu żadnej korzyści, będąc niczym pusty gliniany bożek"28. Obie te wartości jawią się niczym dwa skrzydła ptaka, dzięki którym na wyżyny doskonałej Miłości, Którą jest Bóg, wznosi się ten, kto Jej poszukuje i pragnie Jej zaznania. Zjednoczenie z Bogiem przekłada się także na relacje międzyludzkie. Kiedy serce uwalnia się i obmywa od trującego skażenia grzesznej nieczystości, wówczas człowiek zaczyna postrzegać otaczający go świat w zupełnie innej perspekty-

ской Православной Церкви „Православная энциклопедия”, Москва 2009, s. 318-319.

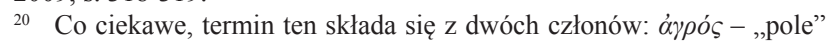
oraz vँ $\pi v o \varsigma$ - ,sen”. Dosłownie oznacza on osobę, która śpi krótko, lub w ogóle pozbawia siebie odpoczynku pilnując dobytku na swoim pastwisku. Pod $\alpha \gamma \rho v \pi v i ́ \alpha$ rozumiano także czas czuwania, pełnienia nocnej warty przez żołnierza, dozorcę, strażnika. W ten sposób nabożeństwo powszechne znane dziś jako „Całonocne Czuwanie” powinno być również dla każdego wiernego okresem stania na straży swego serca i umysłu przed pokusami szatana, który pod pozorem zmęczenia próbuje odwieźć

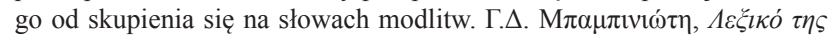

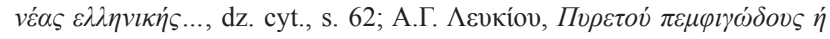

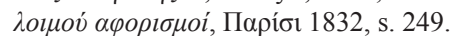

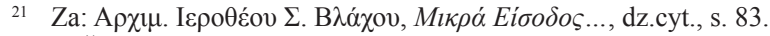

22 T. Špidlík, Duchowość chrześcijańskiego Wschodu. Przewodnik systematyczny, tłum. L. Rodziewicz, wyd. Bratni Zew, Kraków 2005, s. 231.

23 Metropolita Ierotheos uważa, że pojęcie „oczyszczenia serca” należy rozpatrywać na trzy sposoby: po pierwsze, uzdrowienia sił duchowych tak, że rozum, pragnienie i wola człowieka nakierowane są już tylko ku Bogu. Po drugie, uwolnienia się od namiętności i cierpienia. I wreszcie po

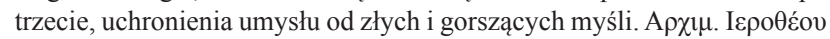

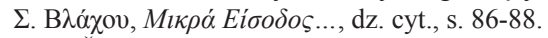

24 T. Špidlík, Duchowość chrześcijańskiego Wschodu..., dz. cyt., s. 232.

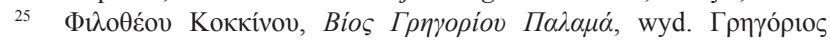

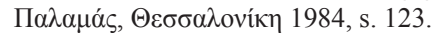

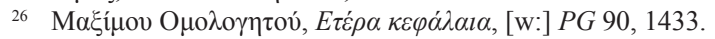

27 Termin ten wywodzi się od greckiego vи́ $\varphi \omega$ - „być trzeźwym, czujnym”. Określani są nim mnisi i teolodzy Kościoła, którzy dążyli do osiągnięcia komunii z Bogiem drogą duchowego skupienia, nieustannej modlitwy, surowej ascezy i szczerego pokajanija.

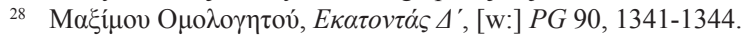

wie, staje się bardziej otwarty i życzliwy wobec innych ludzi i społeczeństwa, w którym żyje, okazując się wzorem do naśladowania. Mając na względzie obraz przyszłego, wiecznego życia wraz z Jego Królem i Władcą, z egoisty i egocentryka, którym był on do tej pory, przemienia się w miłującego Boga (gr. $\varphi \imath \lambda o ́ \theta \varepsilon o \varsigma)$ i drugiego człowieka (gr. $\varphi \imath \lambda \alpha ́ v \theta \rho \omega \pi \circ \varsigma)$, bez względu na to, czy miłują go pozostali. Miłość interesowna ustępuje miejsca miłości bezinteresownej, idealnej i szukającej szczęścia bliźniego ${ }^{29}$.

Przyglądając się bliżej życiu trzech apostołów, o których wspomniano wcześniej, istotnie dochodzi sie do wniosku, że nie jest dziełem przypadku fakt umieszczenia tych, a nie innych Jezusowych uczniów w tej właśnie kolejności. Wśród wszystkich apostołów wydaje się, że to jednak Paweł był tym, który został całkowicie ,zawładnięty" przez Chrystusa, Któremu służył ofiarnie, nieustępliwie i zapalczywie. Nie żali się na trudności i niedogodności, jakich doznaje w swej pracy misyjnej. Przeciwnie, są one powodem do chluby (II Kor 11, 16. 30). Sam też mówi o sobie: „Trudziłem się o wiele bardziej niż inni” (I Kor 15, 10). Paweł to nauczyciel modlitwy, wzywający do nieprzerwanego dziękczynienia Bogu (I Tes 2, 13), ale i człowiek czystego serca, gdyż tylko taki śmiało może rzec, że żyje już nie on, ale żyje w nim Chrystus (Ga 2, 20). Jana Ewangelistę z kolei cechować będzie głęboka i zarazem rzadko spotykana mistyczna kontemplacja tajemnicy Boga. Nienadaremnie Kościół nadał mu przydomek „Teolog" 30 . Prawdziwa teologia bowiem jest wiedzą o Bogu, życiem w Bogu, oglądaniem Boga, to postrzeganie, $\theta \varepsilon \omega \rho i ́ \alpha$ niestworzonego światła. Już pierwsze wersety każdej księgi jego autorstwa świadczą o tym, że tylko oczy człowieka, który wzniósł się na wyżyny życia duchowego są w stanie widzieć rzeczy pozaziemskie. Będąc najbliżej Chrystusa, wtajemniczony on został w najbardziej enigmatyczne zagadnienia dotyczące Stwórcy, jak i tego, co oczekuje ludzkość podczas Paruzji. Apostoł pisał: „To wam oznajmiamy, co było od początku, cośmy usłyszeli o Słowie życia, co ujrzeliśmy własnymi oczami, na co patrzyliśmy i czego dotykały nasze ręce - bo życie objawiło się. Myśmy je widzieli, o nim świadczymy i głosimy wam życie wieczne, które było w Ojcu, a nam zostało objawione - oznajmiamy wam, cośmy ujrzeli i usłyszeli, abyście i wy

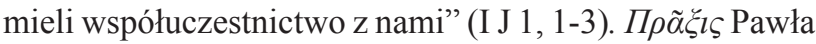
oraz $\theta \varepsilon \omega \rho i ́ \alpha$ Jana kumulują się w Piotrze, który, co prawda, zaparł się Chrystusa, lecz dzięki temu w następstwie stał się paradygmatem pokajanija $(\pi \rho \tilde{\alpha} \xi \iota \varsigma)$. Jako jeden z pierwszych ujrzał pusty grób i zmartwychwstałego Boga w ciele ( $\theta \varepsilon \omega \rho i \alpha)$. Umiłował Go do tego stopnia, że - jak przekazuje efeski biskup - w swej ofiarnej $\dot{\alpha} \gamma \alpha \dot{\pi} \eta \eta$ do Zbawiciela

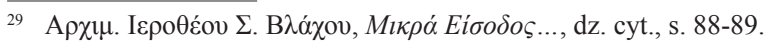

30 Tym mianem Kościół określa jedynie trzy osoby. Oprócz apostoła Jana będzie to Grzegorz z Nazjanzu oraz Symeon Nowy Teolog. Żyjący w XIV w. biskup Konstantynopola Filoteusz Kokkinos do triady tej

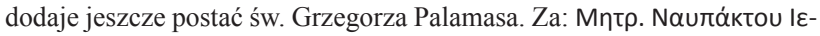

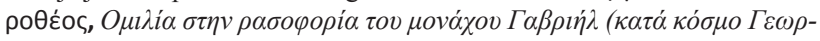

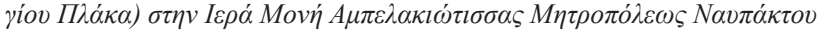

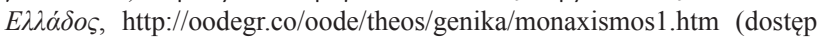
13.01.2016).
} 
wyprzedził całe grono dwunastu ${ }^{31}$, nakłaniając tym samym Jego wyznawców słowami: „miejcie wytrwałą miłość jedni ku drugim, bo miłość zakrywa wiele grzechów" (I P 4, 8). Wiara w Jezusa jako Syna Bożego stała się niczym iskra, która zapłonęła w duszy syna Jonasza, inspirując go do żarliwej służby głoszenia Boskiego Słowa $(\pi \rho \tilde{\alpha} \xi ı \varsigma)$. To jemu oddaje się bezgranicznie, za nic poczytując już wygody i dobra tego świata, oddawszy całe swoje ,ja" Chrystusowi $(\theta \varepsilon \omega \rho i \alpha)$. Piotr wiedział doskonale, że „kto trwa w miłości, trwa w Bogu, a Bóg trwa w nim" (I J 4, 16)

\section{Znacznie poszczególnych słów modlitwy serca}

Każde z czterech określeń (Pan, Jezus, Chrystus, Syn Boży) zawartych w tej prostej, lecz niezwykłej modlitwie, według Eugenikosa posiada również inne zadanie, a mianowicie: obalić błędne nauczanie poszczególnych teologów Kościoła, którzy w pewnym momencie swoich dogmatycznych dociekań zbłądzili. Słowa „Pan” użyto w celu odparcia hipotez Pawła z Samosaty ${ }^{33}$, ,Jezus" - opinii Piotra Folusznika (gr. Kv $\alpha \varphi \varepsilon v ́ \varsigma$ ) patriarchy Antiochii ${ }^{34}$, , Chryste” - przekonań Nestorian ${ }^{35}$, „Synu Boży” - stanowiska monofizytów ${ }^{36}$. Stanowi więc ona niepodważalne trynitarne i chrystologiczne wyznanie wiary.

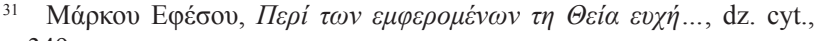
s. 349 .

32 W dziele pt. „O owocach ducha” św. Marek zalicza miłość do jednej $\mathrm{z}$ dziewięciu stopni $\pi \rho \tilde{\alpha} \xi ı$. Wg jego klasyfikacji zajmuje ona ostatnie

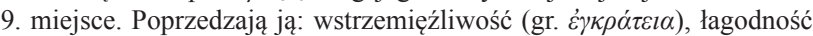
(gr. $\pi \rho \alpha o ́ \tau \eta \varsigma)$, wiara (gr. $\pi i \sigma \tau \iota \varsigma)$, dobroć (gr. $\alpha \gamma \alpha \theta \omega \sigma v ́ v \eta)$, gorliwość

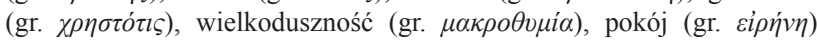

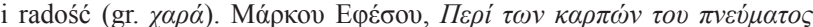
[w:] $\Sigma \omega \tau \dot{\rho} \rho$, t. 12, A $\theta \dot{v} v \alpha$ 1889, s. 341-342.

Utrzymywał on, że tylko Ojciec zasługuje na miano Boga
} prawdziwego, zaś Słowo i Duch są Jego siłami. Logos i Chrystus nie są jednym i tym samym. Jeżeli pierwszy jest siłą, to drugi będzie najwyższym człowiekiem, zrodzonym z Marii, zaś po zstąpieniu na Niego Logosu, miał się On zjednoczyć się z Bogiem stając się z Nim współistotny. П.K.

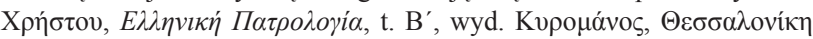
1991, s. 947-949.

34 Autor dodatku o nacechowaniu czysto monofizyckim, umieszczonego

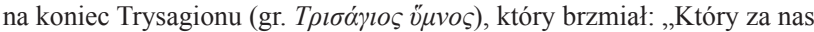

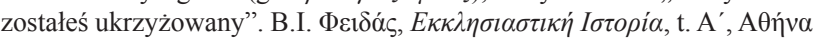
1994, s. 669.

35 Kim innym dla Nestoriusza jest Bóg Logos, a jeszcze kim innym człowiek Jezus. Zatem w przypadku Chrystusa mamy do czynienia z dwiema, zupełnie innymi osobami „w jednym”. Nie do zaakceptowania w jego toku myślenia było wcielenie Samego Boga, które zdaniem patriarchy i jego zwolenników, oznaczało przemianę dwóch natur w jedną złożoną naturę, gdzie Boskość przyjmuje na siebie zupełnie nowe cechy i sposób istnienia a Logos „traci” współistotność z Ojcem. Maria nie mogłaby urodzić Boga, co byłoby możliwie tylko wówczas, gdyby była „boginią”, gdyż „podobne może urodzić tylko podobne”, zatem nie

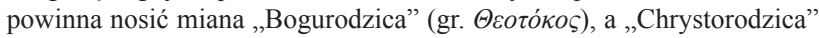

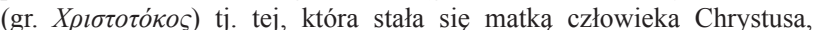

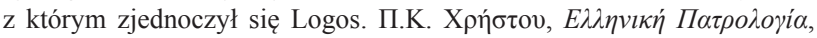

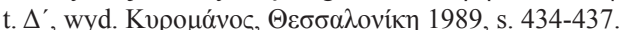

36 Monofizyci byli zdania, że Jezus posiada jedną naturę - Boską, co oznacza, że jest on tylko doskonałym Bogiem. Taka postać rzeczy wynika m.in. z nauczania Eutychesa, według którego dwie natury Chrystusa zjednoczyły się do tego stopnia, że ludzka została pochłonięta przez

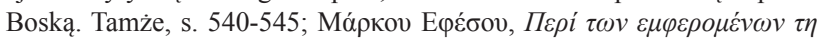

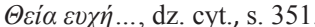

Pomimo, że wiara w drugą Osobę Św. Trójcy, Która przyjęła pełnię ludzkiej natury, jawi się jako jeden ze sztandardowych przedmiotów teologicznej refleksji prawosławia, to jednak samo „suche” wyznanie okazuje się niedostateczne w urzeczywistnieniu zbawienia. Rzeczywiście, wiara powinna być ukierunkowana na prawidłowe relacje człowieka z Bogiem. Głosząc całkowite oddanie Chrystusowi, jako prawdziwemu Bogoczłowiekowi, stworzenie nie może stanąc przed Nim inaczej, jak tylko z pokornym: „zmiłuj się nade mną"37. Tymczasem, dla króla Dawida oczywistym było, że słowa te nie mogły nie wyrażać poczucia grzeszności: „Zmiłuj się nade mną, Boże (...) wymaż moją nieprawość! Obmyj mnie zupełnie z mojej winy i oczyść mnie z grzechu mojego! (...) przeciw Tobie zgrzeszyłem i uczyniłem, co złe jest przed Tobą" (Ps 50, 3-4. 6). Odczytuje on je jako samokontrolę, uświadomienie sobie własnych win i gorzki płacz wynikający z poczucia oddalenia się od Boga, którym psalmista obmywa każdej nocy swoje łoże i posłanie swoje skrapia łzami, szlocha i wzdycha: „przebacz mi i Swą miłością nakieruj naucz mnie co czynić, by do Ciebie ponownie się zbliżyć" (Ps 6, 7). Św. Nil Sorski sprawia wrażenie przychylać się do owej biblijnej wykładni, akcentując, że Pan ponad wszystko wysłuchuje ludzi, jacy uświadomili sobie tragizm swego upadku ${ }^{38}$. Marek Eugenikos podaje jeszcze inny powód, a właściwie „opis osób”, które powinny wypowiadać te słowa na końcu modlitwy serca. Zapisane one zostały w niej w głównej mierze dla „niemowląt w Chrystusie”, które jako jeszcze niedoświadczone, tylko co wstąpiły na pole walki o czystość cnót chrześcijańskich. To oni naśladują ewangelicznego ślepca, który w poszukiwaniu światłości apeluje do przechodzącego Uzdrowiciela z Nazaretu o litość: „Jezusie, Synu Dawida, zmiłuj się nade mną" (Mk 10, 47). Dla

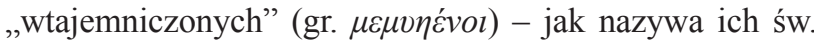
biskup - czyli tych, którzy osiągnęli wyższy pułap zmagań duchowych oraz wyrzekli się catkowicie tego świata, przeciwnie. Ci bowiem są w stanie ograniczyć się jedynie do: „Panie Jezu!”, „Jezu Chryste!”, czy nawet jednego: „Jezu!” - tak, że każde z nich traktowane będzie jako kompletna i wyczerpująca modlitwa, pełna słodyczy i radości ${ }^{39}$.

Święty pochwala również regułę wymawiania modlitwy z dołączeniem tej prośby w liczbie mnogiej ${ }^{40}$ tzn.:

Митр. Антоний (Блум), Школа молитвы, wyd. Христианская жизнь, Клин 2004, s. 79

$38 \mathrm{Za:} \mathrm{Святитель} \mathrm{Игнатий} \mathrm{(Брянчанинов),} \mathrm{Слово} \mathrm{о} \mathrm{молитве} \mathrm{Иису-}$ совой [w:] Полное собрание творений святителя Игнатия Брянчанинова, t. II, red. А.Н. Стрижев, wyd. Паломник, Москва 2006, s. 217.

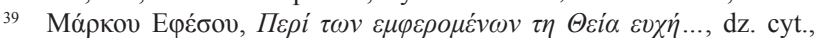
s. 350 .

40 Wsłuchując się w treść prawosławnych tekstów nabożeństw, łatwo można zauważyć, że bezsprzeczna większość z nich, zapisana została w pierwszej osobie liczby mnogiej (wyjątek stanowią niektóre modlitwy kapłana np. podczas Boskiej Liturgii św. Jana Złotoustego jak choćby: Nikt nie jest godny ... (cs. Никтоже достоин ...) czy modlitwa przed Eucharystią: Wierzę Panie i wyznaję... (cs. Верую Господи и исповедую...). Kościół podkreśla tym samym, że służba Boża posiada charakter wspólnotowy - wszyscy modlą się za wszystkich. Wzór takiego właśnie podejścia przekazał sam Chrystus w modlitwie „Ojcze nasz”: „chleba naszego powszedniego daj nam (...)”, ,odpuść nam winy nasze (...)”, ,nie wwódź nas na pokuszenie (...)”, „,nas zbaw ode złego (...)”. 
„zmiłuj się nad nami!”, która nie może nie emanować przejawem miłości wobec bliźniego, gdyż to „miłość jest wypełnieniem Prawa i Proroków"41, a każde przykazanie i duchowe działanie zawiera i rekapituluje ją w sobie. Miłość nie tylko przyciąga do komunii modlitwy wszystkich naszych braci. Jednocześnie, dzięki swemu wyznaniu i głoszeniu Boga panującego nad wszystkim i wszystkimi, „Zmusza” ona Go do wylania Przezeń jeszcze większego Swego ogromnego miłosierdzia na cały świat. Miłosierdzie natomiast - pisze on dalej - schodzi na człowieka oddanego prawdziwej wierze $\mathrm{w}$ dogmaty i wypełnianiu przykazań, do których popycha nas ten krótki werset mo-

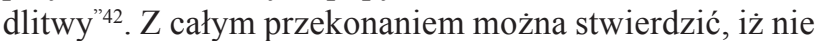
może być mowy o koincydencji, kiedy hierarcha traktując o jej końcowej części porusza zagadnienie dobrotli-

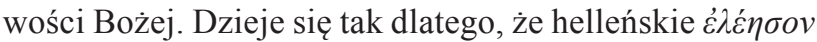
- „zmiłuj się”, dzięki innemu, ściśle z nim związanemu tym samym słoworodem i podobnie brzmiącą wymową, greckiemu terminowi č̉ $\alpha ı$ - - „oliwa”, „olej” nabrało bardzo ważnego i symbolicznego znaczenia. Biblia obfituje w historie i przypowieści poświadczające słuszność tego założenia. Pojawiające się już na stronicach Księgi Rodzaju w opowiadaniu o Noe drzewo oliwkowe (Rdz 8, 8-13) okazało się znakiem ustania kataklizmu i litości Jahwe nad umęczoną potopem ziemią i jej mieszkańcami. W przekazie o miłosiernym Samarytaninie oliwa ${ }^{43}$ jawi się jako skuteczny środek-lekarstwo na poważne rany. Apostołowie jako wyraz współczucia w ludzkim cierpieniu, ,wielu chorych namaszczali olejem i uzdrawiali” (Mk 6,13) i zachęcali: „Choruje ktoś wśród was? Niech sprowadzi kapłanów Kościoła, by się modlili nad nim i namaścili go olejem w imię Pana (...)" (Jk 5, 14). Takie właściwości przypisywano mu i w starożytnym Babilonie, gdzie nawet lekarze nazywani byli asû tzn. „opiewacze oliwy”. Św. Cyryl Jerozolimski wyjaśnia, że samo namaszczenie ciała oliwą nie jest dziełem uświęconym samym w sobie, lecz to Życiodajny Duch koi wszelkie rany ciała i duszy ${ }^{44}$. Oliwkowy olej ucieleśniać ma po-

\footnotetext{
41 Św. Marek ewidentnie posiłkuje się tutaj Listem do Rzymian: „Nikomu nie bądźcie nic dłużni poza wzajemną miłością. Kto bowiem miłuje bliźniego, wypełnił Prawo. Albowiem przykazania: Nie cudzołóż, nie zabijaj, nie kradnij, nie pożądaj, i wszystkie inne - streszczają się w tym nakazie: Miłuj bliźniego swego jak siebie samego! Miłość nie wyrządza zła bliźniemu. Przeto miłość jest doskonałym wypełnieniem Prawa" (Rz 13, 8-10).

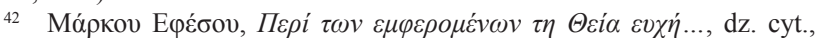
s. 350 .

43 Tutaj w połączeniu z winem (Łk 10, 30-37).

44 Za: M. Lurker, Stownik obrazów i symboli religijnych, tłum. ks. Kazimierz Romaniuk, wyd. PALLOTINUM, Poznań 1989, s. 156-157.
}

nadto ponowne zjednoczenie z Bogiem, od Którego odłączył się człowiek popadający w grzech, ale i Jego bogatą cudotwórczą łaskę, którą wylewa na miłujących Go ludzi, lecz znajdujących się w potrzebie ${ }^{45}$. Zatem „Zmiłuj się nade mną/nami”, to inaczej „przebacz”, ,pomóż”, ,wybaw” oraz „ochroń mnie i tych, za których się modlę pod skrzydłami Twej porywającej miłości”. Innymi słowy, to ofiarna prośba o miłosierdzie.

Należałoby nadmienić, że Eugenikos w swych rozmyślaniach na temat modlitwy Jezusowej ani razu nie dodaje do niej wyrazu: „grzesznym” (,Panie Jezu Chryste, Synu Boży, zmiłuj się nade mną grzesznym"). Nie oznacza to na pewno, że go bagatelizuje. Wynika to najprawdopodobniej z faktu, że jednym z pierwszych, który praktykował ją z tym dodatkiem, był żyjący dopiero w I poł. XIV w. wielki mistrz nieustannej modlitwy św. Grzegorz Synaita ${ }^{46}$. Stąd też, za czasów Marka, kiedy termin ten dopiero wkraczał do „twierdzy modlitwy i prawosławia" ${ }^{\prime 47}$, mógł być hierarsze i wielu innym po prostu jeszcze nieznany.

\section{Zakończenie}

Krótka objętościowo, ale obszerna w przekazie modlitwa odkrywa cząstkę mądrości i mocy Bożej. „Jej słowa są niczym bukiet kwiatów zerwany z okazałego krzewu - jak świetnie ujmuje grecki pasterz - i może je zbierać każdy"48. Owoce jednak, które te skrywają w sobie, skosztują ci, którzy nie poprzestaną jedynie na ich podziwianiu

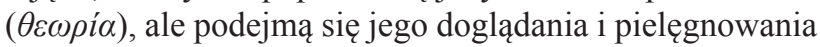
$(\pi \rho \tilde{\alpha} \xi l \varsigma)^{49}$.

\section{Wyjaśnienie skrótów pozycji obcojęzycznych}

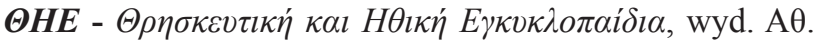

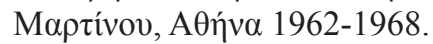

$\boldsymbol{P} \boldsymbol{G}$ - J.- P.w Migne, Patrologiae Cursus Completus, Series Graeca, Paryż 1857-1866.

\footnotetext{
45 Митр. Антоний (Блум), Школа молитвы..., dz. cyt., s. 79-80.

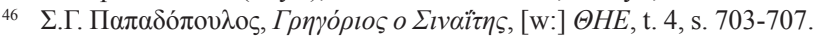

47 Takiego m.in. określenia, używa św. hierarcha wobec modlitwy Je-

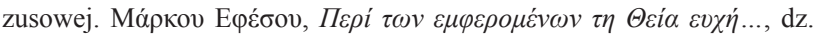
cyt., s. 350.

48 Tamże.

49 Tamże.
} 


\section{Bibliografia}

Lurker M., Stownik obrazów i symboli religijnych, tłum. ks. Kazimierz Romaniuk, wyd. PALLOTINUM, Poznań 1989.

Pańkowski J., Duchowość w prawosławiu prawosławiu, [w:] Przegląd Religioznawczy, wyd. Polskie Towarzystwo Religioznawcze, Warszawa 2012, Nr 2 (244), s. 75-88.

Špidlík T., Duchowość chrześcijańskiego Wschodu. Przewodnik systematyczny, thum. L. Rodziewicz, wyd. Bratni Zew, Kraków 2005.

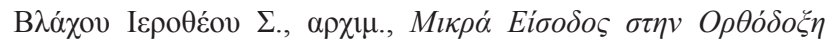

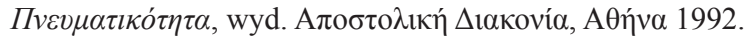

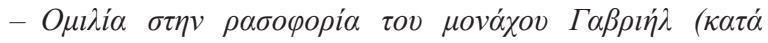

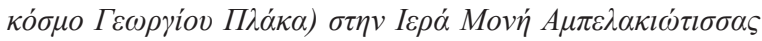

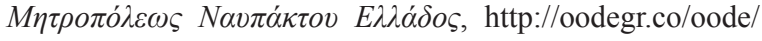
theos/genika/monaxismos1.htm (dostęp 13.01.2016).

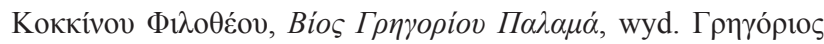

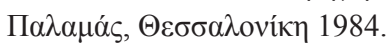

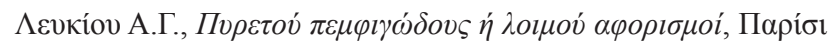
1832.

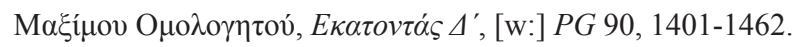

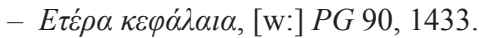

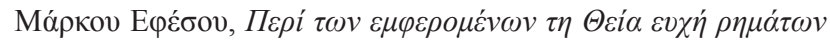

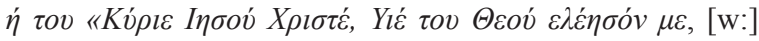

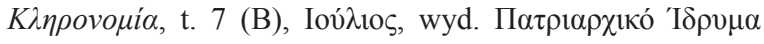

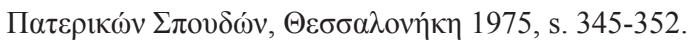

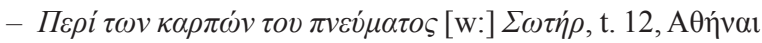
1889, s. 341-342.

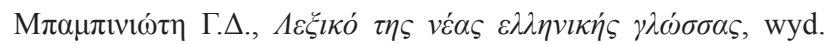

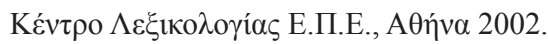

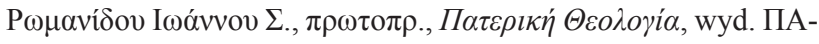

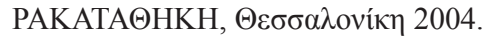

Бернацкий М.М., Илия Э'кдик, [w:] Православная энщиклопедия, t. 22, wyd. Церковно-научный центр Русской Православной Церкви „Православная энциклопедия”, Москва 2009, s. 318-319.

(Блум) Антоний, митр., Школа молитвы, wyd. Христианская жизнь, Клин 2004.

(Брянчанинов) Игнатий святитель, , Письмо к А.С. Норову. 응 3, [w:] Полное собрание творений святителя Игнатия Брянчанинова, t. VI, red. А.Н. Стрижев, wyd. Паломник, Москва 2004, s. 773-774.

- Слово о молитве Иисусовой [w:] Полное собрание творений святителя Игнатия Брянчанинова, t. II, red. А.Н. Стрижев, wyd. Паломник, Москва 2006, s. 216-217.

Не оставляй Божественной молитвы. Оптинские стариьы о молитве Иисусовой, red. посл. Зоя Афанасьева, Святая Гора Афон 2014.

Симеон Солунский, блаж., Обяснение православных богослужений, обрядов и таинств, wуd. Оранта, Москва 2009.

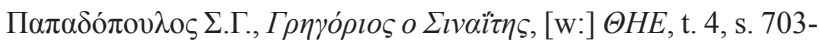
707.

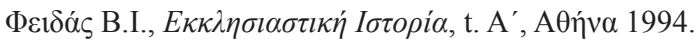

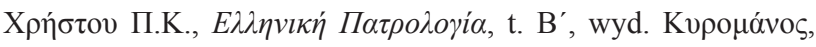

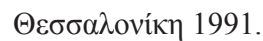

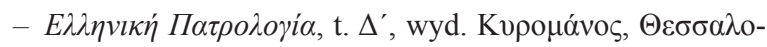
víkп 1989.

Rozmiar artykułu: 0,8 arkusza wydawniczego 


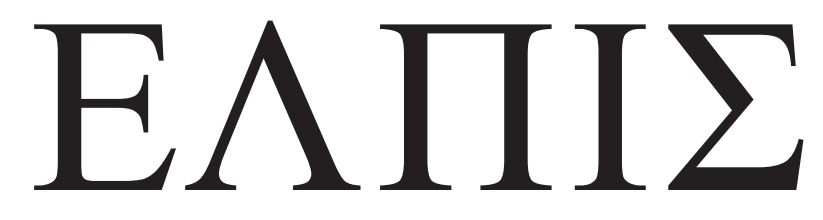

CZASOPISMO TEOLOGICZNE KATEDRY TEOLOGII PRAWOSŁAWNEJ UNIWERSYTETU W BIAŁYMSTOKU

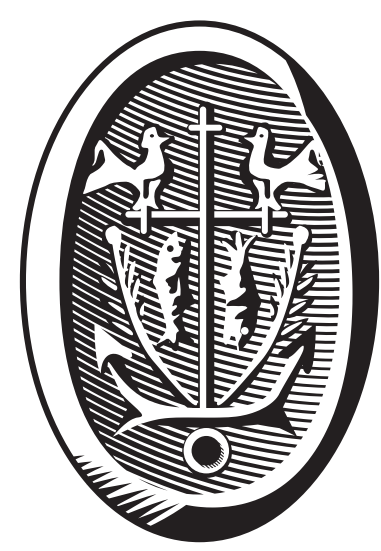

ADRES REDAKCJI

ul. Ludwika Zamenhofa 15, 15-435 Białystok, Polska tel. 85 745-77-80, e-mail: elpis@uwb.edu.pl www.elpis.uwb.edu.pl 